\title{
Analysis of interrelationship between usefulness of management accounting systems, interactive budget use and job performance
}

\author{
Muhammad Dahlan ${ }^{a^{*}}$
}

${ }^{a}$ Department of Accounting, Economics and Business Faculty, University of Padjadjaran, Indonesia

\section{CH R O I C L E ABSTRACT}

Article history:

Received: March 12, 2019

Received in revised format: April

102019

Accepted: April 14, 2019

Available online:

April 14, 2019

Keywords:

MAS information

Interactive Budget Use

Job Performance

\begin{abstract}
This study investigates the importance of management accounting systems (MAS) and interactive budget use at middle to lower level employees in the public service administration. The study tries to understand the effect of interactive budget use on the interrelationship between MAS information and job performance. The study sends a questionnaire to each potential participant of 40 public administration offices located at West Java Province of Indonesia. Out of 120 distributed, the study obtains 78 usable data and analyses using Path-Analysis. The study finds that MAS information improved interactive budget use. Both variables of MAS information and interactive budget use significantly boost the job performance. However, interactive budget use did not moderate in the relationship between MAS information and job performance. The study implies that director/chairman and managers can open communication channels to subordinate to increase MAS information which leads to the improvement interactive budget use in order to generate excellent performance. This study confirms that MAS information should increase the implementation of interactive budget use to leverage the administration service and civil services in gaining competitive advantage. The study investigates the importance of MAS information and interactive budget use at middle to lower level employees in public service administration office.
\end{abstract}

\section{Introduction}

Nowadays, many researchers in the area of management acoounting have paid less attention in the public sector (Lau \& Tan, 1998; Brownell \& Mechant, 1990; Brownell \& Dunk, 1991; Nouri \& Parker 1998; Chong \& Chong, 2002; Chia, 1995; Chong \& Eggleton, 2003). Abernethy and Brownell (1999) investigated how management accounting control systems play an essential role in shaping organizational change. They stated that interactive budget use could be a moderating variable in the relationship between strategic change and hospital performance. Bisbe and Otley (2004) performed an investigation on the relationship between innovation and MAS but their results did not support that an interactive use of MCS could lead to innovation within the organization. In this research, we investigate whether or not there is a positive relationship between the levels of quality MAS information, interactive budget use and job performance.

* Corresponding author.

E-mail address: dahlanm2004@yahoo.com (M. Dahlan) 


\section{Literature Review and Hypothesis Development}

Chenhall and Morris (1986) formalized the four infornation characteristics of MAS. The summary of the dimension information characteristics; namely scope (narrow to broad), timeliness (slow/standard to fast/customized to requests), aggregation (from summarized to very detailed), and integration (information for the department only to information from other department). There have been many studies adopted four dimensions of information characteristics in the manuscript, actually in the privat sector, for example manufacturing company. Soobaroyen and Poorundersing (2008) suggested MAS information in manufacturing companies to have a positive effect on firm performance. The same findings have been reported in other studies, for example: Fisher (1996), Chong (2004), Chia (1995), Mia and Chenhall (1994), and Gul and Chia (1994). MAS information had a positive effect on interactive budget use (Chenhall \& Langfield-Smith, 1998; Chenhall, 2003; Haldma \& Laats, 2002; Naranjo-Gil \& Hartmann, 2006). Interactive budget use has positive impact on job performance (Abernethy \& Brownell, 1999; Nouri \& Parker, 1998; Chong \& Chong, 2002). Many studies have suggested interactive budget use or budget as a style of performance evaluation and its impact on job performance. Budget style of performace evaluation influenced on the job perfoemance (Lau \& Tan, 1998; Brownell \& Mechant, 1990; Brownell \& Dunk, 1991). However, less attension has been devoted on management accounting to examine whether or not MAS information has any positive impact on interactive budget use and indirect effect to increase job performance. The proposed study tries to examine such relationship and Fig. 1 demonstrates the summary of the proposed study.

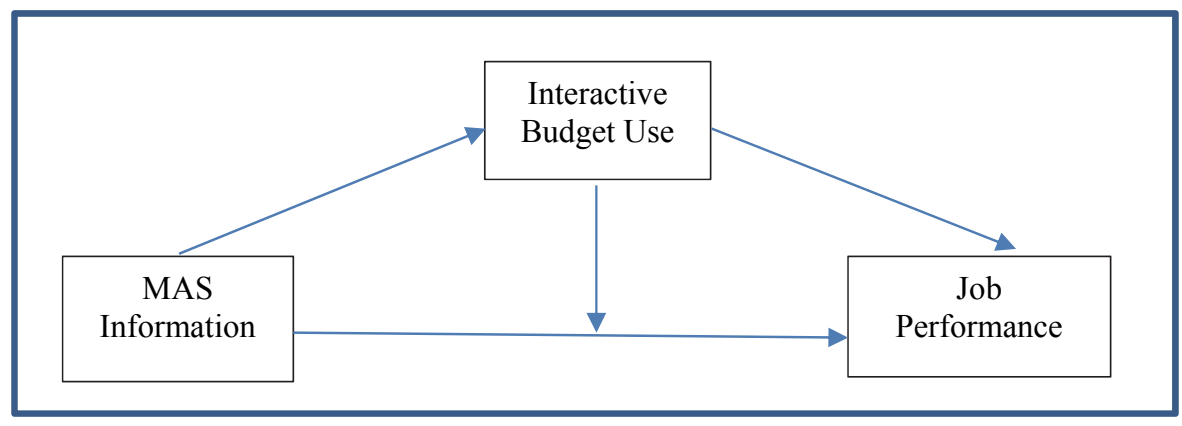

Fig. 1. Conceptual of Research Framework

According to Fig. 1, we examine the effect of MAS information on Interactive Budget Use and the effect of Interactive Budget Use on Job Performance. We also examine the effect of MAS on Job performance where Interactive Budget Use plays a mediator role on this relationship.

$\mathrm{H}$ : There is a positive relationship between the level of quality MAS information, interactive budget use and job performance:

1. MAS information has a direct on job performance.

2. MAS information has a direct on interactive budget use.

3. Interactive budget use has a direct effect on job performance.

4. Interactive budget use ahs a indipendence variable in the performance evaluation perspective view.

\section{Methodology}

\subsection{Questionaire distribution and survey administration}

Each potential participant of 40 public administration offices west Java in Indonesia was sent a questionaire together with a covering latter and a stamped sefl-addressed envelope, with a request to respond within two weeks. If they did not respond, we contacted them to get the necessary information. 
From 120 distributed, we obtained 78 usable data points where we analysed them using Path-Analysis. Each office, were distributed three questionaires in operation, finance and planning section/departements.

\subsection{Instruments measurement}

Management Accounting Systems. The instrument measurement for the MAS information was based on Chenhal and Morris (1986), because it was used, extensively. We used three group dimensions relating infomation characteristics of scope ( 5 items information), timeliness (4 items information), and integration dimenstions ( 3 items information). The dimensions of integration were not relevant to government office.

Interactive Budget Use. The instrument measurement was fully adopted from the Abernethy and Brownell (1999). The respondents were asked the extent to which with 3 items in order of the five Likertscale very disagreed and very agreed.

Job Performance. Job performence instrument for measurement was replicated by the Mahoney, et al. $(1963,1965)$.

\section{Results and Findings}

\subsection{Results}

78 usable data points were analysed using Path-Analysis and the results are shown in Table 1 as follows,

Table 1

Descriptive statistics, reliability, validity, and correlation matrix ${ }^{\mathrm{a}}(\mathrm{n}=78)$

\begin{tabular}{lcccccc}
\hline \multicolumn{1}{c}{ Variables } & Min & Max & $\begin{array}{c}\text { Mean } \\
(\mathbf{s d})\end{array}$ & $\begin{array}{l}\text { MAS } \\
\text { information }\end{array}$ & $\begin{array}{c}\text { Correlations } \\
\text { Interactive } \\
\text { budget use }\end{array}$ & $\begin{array}{l}\text { Job } \\
\text { performance }\end{array}$ \\
\hline MAS information & 30.00 & 60.00 & $\begin{array}{l}42.23 \\
(5.87)\end{array}$ & - & - \\
Interactice budget use & 12.00 & 20.00 & $\begin{array}{l}16.00 \\
(1.76)\end{array}$ & $0.489 *$ & \\
Job Performance & 24.00 & 45.00 & $\begin{array}{l}35.38 \\
(4.27)\end{array}$ & $0.609 * *$ & $0.548^{* *}$ \\
\hline
\end{tabular}

a) Pearson correlation (two-tailed test) were computed. *correlation is significant at the 0.05 level; and ** is significant at the 0.001 level.

Kaiser-Meyer-Olkin measure of sampling adequacy yields $0.867,0.653,0.881$ for MAS information and Interactive budget and Job performance, respectively and Cronbach alpha for these three variables were $0.911,0.890$ and 0.646 , respectively which confirm the reliability of the test (Nunnally, 1978; Kaiser \& Rice, 1974). In our survey, out of 78 respondents, there were 47 male and 31 female. Among the respondents undergraduat level was 48 and postgraduat level was 30.

Table 2

The results of the direct and the indirect effects of MAS on job performance

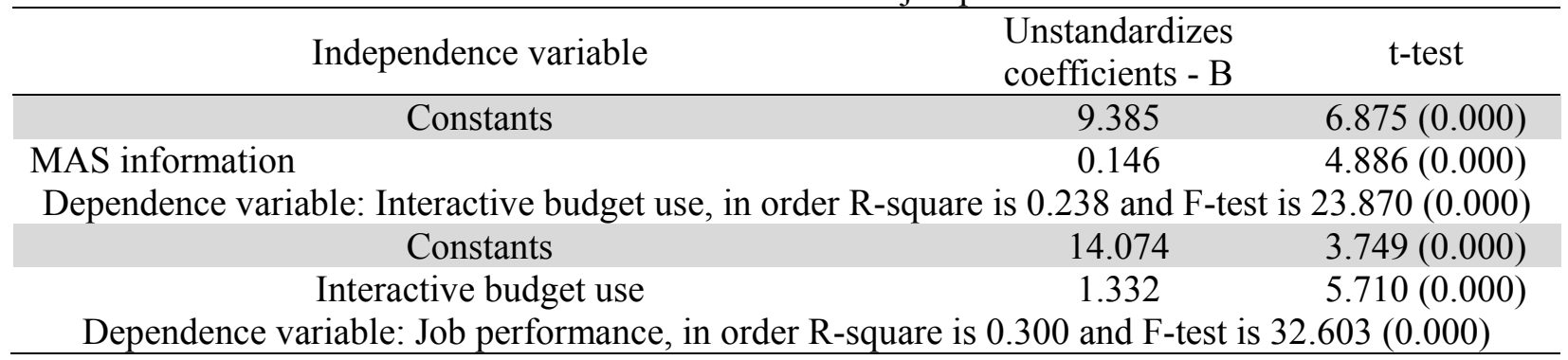


According to Table 2, MAS information maintains positive and significant effect on job performance, and interactive budget use has positive effect on job performance. Therefore $h 2$ and $h 3$ were supported.

\section{Table 3}

The results of the effect of interactive budget use in the relationship between usefulness of management accounting systems and job performance, with three step level.

\begin{tabular}{lcccc}
\hline \multicolumn{1}{c}{ Independence variable } & R-Square & F-test & $\begin{array}{c}\text { Unstandardizes } \\
\text { coefficients - B }\end{array}$ & t-test \\
\hline $\begin{array}{c}\text { Constants } \\
\text { MAS information }\end{array}$ & 0.370 & 44.704 & 15.368 & $5.091(0.000)$ \\
$\quad \begin{array}{c}\text { Constants } \\
\text { MAS information }\end{array}$ & 0.453 & $(0.000)$ & 0.443 & $6.689(0.000)$ \\
$\quad$ Interactive budget use & & $(0.000)$ & 7.862 & $2.179(0.000)$ \\
$\quad \begin{array}{c}\text { Constants } \\
\text { MAS information }\end{array}$ & \multirow{2}{*}{0.456} & 20.671 & 0.326 & $4.572(0.000)$ \\
$\quad$ & & $(0.000)$ & 0.800 & $3.360(0.000)$ \\
Interactive budget use & & & 0.652 & $-0.306(0.760)$ \\
Moderating MAS.Budget & & & 1.719 & $1.303(0.197)$ \\
Dependence variable: Job Performance & & -0.020 & $-0.659(0.512)$ \\
\hline
\end{tabular}

According to the results of Table 3, the results of step-wise regression analysis have indicated the level of quality and sophistication of MAS information and interactive budget use had positive effect on job performance (support $h 1$ and $h 3$ ). Therefore $h 4$ was supported.

\section{Conclusion}

In our survey, MAS information have positive effect on job performance. That is consistent on the prior studies. For instance, Soobaroyen and Poorundersing (2008) suggest that MAS information maintained positive and significant effect on firm performance. The same findings were found by Fisher (1996); Chong (2004); Chia (1995); Dahlan (2017); Mia and Chenhall (1994); and Gul and Chia (1994). MAS information also had a positive and significantly effect on interactive budget use and the results are consistent with other studies (e.g. Chenhall \& Langfield-Smith, 1998; Chenhall, 2003; Haldma \& Laats, 2002; Naranjo-Gil \& Hartmann, 2006). Interactive budget use has positive and significant effect on job performance and the findings are in line with the previous studies (Abernethy \& Brownell, 1999; Nouri \& Parker, 1998; Dahlan et al., 2007; Chong \& Chong, 2002). Budget style also influenced on the job perfoemance and this result is confirmed with other findings (e.g. Lau \& Tan, 1998, Brownell \& Merchant, 1990; Brownell \& Dunk, 1991).

\section{Acknowledgement}

This research work is supported by Hibah Internal Unpad (HIU), University of Padjadjaran, Indonesia year of 2018.

\section{References}

Abernethy, M. A., \& Brownell, P. (1999). The role of budgets in organizations facing strategic change: an exploratory study. Accounting, Organizations and Society, 24(3), 189-204.

Brownell, P., \& Dunk, A. S. (1991). Task uncertainty and its interaction with budgetary participation and budget emphasis: some methodological issues and empirical investigation. Accounting, Organizations and Society, 16(8), 693-703.

Brownell, P., \& Merchant, K. A. (1990). The budgetary and performance influences of product standardization and manufacturing process automation. Journal of Accounting Research, 28(2), 388-397. 
Chenhall, R. H. (2003). Management control systems design within its organizational context: findings from contingency-based research and directions for the future. Accounting, organizations and society, 28(2-3), 127-168.

Chenhall, R. H., \& Langfield-Smith, K. (1998). Adoption and benefits of management accounting practices: an Australian study. Management accounting research, 9(1), 1-19.

Chenhall, R. H. and Morris, D. (1986). The impact of structure, environment and interdependence on the perceived usefulness of management accounting systems. The Accounting Review, 61(1), 16-35.

Chia, Y. (1995). Decentralization, management accounting control (MACS) information characteristic and their interaction effects on managerial performance: a Singapore study. Journal of Business Finance and Accounting, 22(6), 811-830.

Chong, V. K. (2004). Job relevant information and its role with task uncertainty and management accounting systems on managerial performance. Pacific Accounting Review, 16(2), 1-22.

Chong, V. K., \& Chong, K. M. (2002). Budget goal commitment and informational effects of budget participation on performance: A structural equation modeling approach. Behavioral Research in Accounting, 14(1), 65-86.

Chong, V. K., \& Eggleton, I. R. (2003). The decision-facilitating role of management accounting systems on managerial performance: the influence of locus of control and task uncertainty. Advances in Accounting, 20, 165-197.

Dahlan, M. (2017). Moderating effect of usefulness management accounting system on the relationship between innovation and firm performance: evidence from Bandung District, West Java, Indonesia. International Journal of Applied Business and Economic Research, 15(25), 179-188.

Dahlan, M., Auzair, S. Md., \& Wan-Ibrahim, W. M. (2007). Tight budgetary control, business strategy, external environment and firm performance. Malaysian Accounting Review, 6(2), 81-97.

Fisher, C. (1996). The impact of perceived environmental uncertainty and individual differences on management information requirements: a research note. Accounting, Organizations and Society, 21(4), 361-369.

Gul, F. A., \& Chia, Y. M. (1994) the effects of management accounting systems, perceived environmental uncertainty and decentralization on managerial performance: a test of three-way interaction. Accounting, Organizations and Society, 19(4/5), 413-426.

Haldma, T., \& Laats, K. (2002). Contingency influencing the management accounting practices of Estonia manufacturing companies. Management Accounting Research, 13(4), 379-400.

Kaiser, H. F., \& Rice, J. (1974). Little jiffy, mark IV. Educational and psychological measurement, 34(1), 111-117.

Lau, C. M., \& Tan, J. J. (1998). The impact of budget emphasis, participation and task difficulty on managerial performance: a cross-cultural study of the financial services sector. Management Accounting Research, 9(2), 163-183.

Mahoney, T. A., Jerdee, T. H. \& Carrol, S. J. (1963). Development of Managerial Performance: a Research Approach. Cincinnati: South western Publishing.

Mahoney, T. A., Jerdee, T. H., \& Carrol, S. J. (1965). The job of management. Industrial relation, pp. 97-110.

Mia, L., \& Chenhall, R. H. (1994). The usefulness of management accounting systems, functional differentiation and managerial effectiveness. Accounting, Organizations and Society, 19(1), 1-13.

Naranjo-Gil, D., \& Hartmann, F. (2006). How top management teams use management accounting systems to implement strategy. Journal of Management accounting research, 18(1), 21-53.

Nouri, H. and Parker, R. J. (1998). The relationship between budget participation and job performance: the roles of budget adequacy and organizational commitment. Accounting, Orgnnizatiom and Society, 23(5/6), 467-483.

Nunnally, J. C. (1978). Psychometric theory. 2d ed. New York: McGraw Hill, Inc.

Soobaroyen, T., \& Poorundersing, B. (2008). The effectiveness of management accounting systems: evidence from functional managers in a developing country. Managerial Auditing Journal, 23(2), 187219. 
(C) 2019 by the authors; licensee Growing Science, Canada. This is an open access article distributed under the terms and conditions of the Creative Commons Attribution (CCBY) license (http://creativecommons.org/licenses/by/4.0/). 